\title{
Circadian biomarkers in patients with bipolar disorder: promising putative predictors of lithium response
}

Pierre Alexis Geoffroy ${ }^{1,2,3,4^{*}}$, Bruno Etain ${ }^{4,5,6}$, Sarah Sportiche $e^{1,2,3,4}$ and Frank Bellivier ${ }^{1,2,3,4}$

\begin{abstract}
Bipolar disorder (BD) is a common, severe mental disorder with a high recurrence rate. Lithium ( $\mathrm{L} i$ ) is the cornerstone of $\mathrm{BD}$ treatments to reduce recurrence, suicide, and mortality risks. However, only $30 \%$ of patients treated with Li achieve complete remission, and few markers of the response to treatment have yet been identified for application in routine practice. Circadian biomarkers may be relevant predictors of individual responses to Li because (1) Li has been shown to affect circadian rhythms, (2) disrupted circadian rhythms are a core expression of susceptibility to BD, and (3) circadian abnormalities during euthymia are associated with relapses.
\end{abstract}

Keywords: Lithium salts; Lithium carbonate; Lithium acetate; Circadian rhythms; Sleep; Chronobiology; Circadian genes; Recurrences; Remission; Mood stabilizers

\section{Correspondence}

Bipolar disorder (BD) is a common, severe mental disorder with an onset before the age of 21 years in half the individuals affected (Geoffroy et al. 2013c; Phillips and Kupfer 2013). BD impairs functioning and decreases health-related quality of life. BD is the fourth most important contributor to the global disease burden among mental, neurological, and substance use disorders (Scientific Advisory Board and the Executive Committee of the Grand Challenges on Global Mental Health et al. 2011). The severity and poor prognosis of BD reflect the high rate of recurrence, with a mean recurrence rate of $60 \%$ within 2 years of an index episode, despite medications (Geddes and Miklowitz 2013).

Lithium ( $\mathrm{Li})$ is the first-line treatment of $\mathrm{BD}$ and the cornerstone of treatment for preventing relapses and recurrences of any episodes of either polarity (Grunze et al. 2009; Yatham et al. 2009; Goodwin 2009; Grunze et al. 2010). Furthermore, it is the only treatment shown to decrease suicide risk effectively (Yerevanian and Choi 2013). Li has also been shown to decrease the risk of

\footnotetext{
* Correspondence: pierre.a.geoffroy@gmail.com

'Inserm, U1 144, Paris F-75006, France

${ }^{2}$ AP-HP, GH Saint-Louis - Lariboisière - Fernand Widal, Pôle Neurosciences, Paris CEDEX 10 75475, France

Full list of author information is available at the end of the article
}

non-suicide mortality in patients with BD (MüllerOerlinghausen et al. 1992). However, naturalistic studies have shown that about $40 \%$ of the BD patients treated with $\mathrm{Li}$ show no improvement (non-responders, NRs), about $30 \%$ are partial responders (PRs), and only 30\% are excellent responders (ERs), presenting complete remission for two full years (Solomon et al. 1995; Maj et al. 1995; Baldessarini and Tondo 2000; Garnham et al. 2007). In addition, prophylactic efficacy can be evaluated only after at least 2 years of treatment.

Few reliable and reproducible predictors of individual responses to Li have been proposed: history of prophylactic response to $\mathrm{Li}$ in first-degree relatives, course of the episode, and complete remission between episodes (Kleindienst et al. 2005). Other clinical markers have been put forward, but their replication has been inconsistent: manic-depressive sequence, age at onset, predominant polarity, polarity of the first episode, BD subtype, atypical features (mainly psychotic symptoms, interepisodic residual symptomatology, and rapid cycling), comorbidities, and temperaments (Garnham et al. 2007; Grof 2010; Schulze et al. 2010; Pfennig et al. 2010; Rybakowski et al. 2013).

Thus, therapeutic response is variable, and it remains difficult for clinicians to identify the patients most likely to respond before lengthy Li trials. These data highlight the need to identify biomarkers predictive of individual 
responses to $\mathrm{Li}$, to improve care plans and the prognosis of patients with BD. However, no such predictors have yet been identified for application in routine practice (Geoffroy et al. 2014).

Circadian biomarkers are potential markers for predicting the response to $\mathrm{Li}$ because $\mathrm{Li}$ is thought to help stabilize circadian rhythms in BD and to prevent circadian rhythm desynchronization (Klemfuss 1992). Indeed, Li slightly lengthens the circadian period of behavioral rhythms and delays the phase of behavioral and physiological circadian rhythms (such as sleep-wakefulness and body temperature rhythms) in many species, from healthy and affected humans to rats (Johnsson et al. 1983; Pflug and Engelmann 1987; Klemfuss and Kripke 1995). The hypothesis of a circadian mode of action for $\mathrm{Li}$ is of particular interest because patients with $\mathrm{BD}$ present circadian abnormalities in all phases of the disorder (McClung 2007; Harvey 2008; Etain et al. 2011; McClung 2013). Indeed, such abnormalities occur during acute phases of depression (insomnia, early awakening, hypersomnia) and mania (decrease in the need for sleep). In addition, circadian rhythm and sleep disturbances often precede recurrences and may serve as predictors of a new mood episode. Some patients suffer from seasonal recurrences of depression or mania: $25 \%$ of BD patients for depression and 15\% for mania (Geoffroy et al. 2013a). These circadian abnormalities are also observed during stable phases of normal mood (euthymia) and are thus considered to be a 'trait' of BD. During euthymia, BD patients are more likely than healthy controls to present an evening chronotype, hypersensitivity to disruptive rhythms (jet lag, post-partum, shift work, night vigils, etc.), sleep/wake pattern abnormalities (sleep stability, sleep latency and duration, waking after sleep onset, sleep quality, diurnal activity, and daytime dysfunction), biochemical abnormalities, including melatonin secretion (sleep hormone) and melatoninergic hypersensitivity to light (Hallam et al. 2006; McClung 2007, 2013).

Several independent genetic association studies have implicated circadian or melatonin pathway genes, such as CLOCK, GSK3 $\beta$, NPAS2, ARNTL1, PER3, NR1D1, and ASMT (Milhiet et al. 2011), in susceptibility to BD. Polymorphisms associated with BD may be responsible for circadian rhythm disturbances, as recently observed for a common variant of ASMT associated with BD (Etain et al. 2012; Geoffroy et al. 2013b). Circadian rhythm instability, through its contribution to the underlying neurobiology and genetics of $\mathrm{BD}$, appears to be a major candidate endophenotype for studies aiming to identify the factors associated with treatment response in BD (Hasler et al. 2006).

$\mathrm{Li}$ acts at the molecular level, by modulating the dynamics of clock gene expression and protein rhythms in the peripheral tissues and suprachiasmatic nuclei (the central pacemaker of circadian rhythms) (Etain et al.
2011). For example, $\mathrm{Li}$ is known to affect the expression of two key circadian genes, inhibiting GSK3 $\beta$ expression and activating Clock transcription. It has also been shown to rescue the manic-like behavior of mice transgenic for GSK3 $\beta$ and Clock (Prickaerts et al. 2006; Jope and Roh 2006; Roybal et al. 2007). It is also suggested that the neurobiological mechanisms by which $\mathrm{Li}$ influences circadian rhythms may involve Rev-Erb $\alpha$, the protein product of the NR1D1 gene, which is a phosphorylation target of GSK3. Li inhibits GSK3 that in turn cannot phosphorylate the Rev-Erb $\alpha$ protein which degrades (Can et al. 2014). Furthermore, Li has demonstrated to improve diurnal activity rhythm and periodic activity alterations in transgenic mice with neuron-specific expression of mutant Polg (D181A) an animal model with generated chronobiological abnormalities (Kato et al. 2007).

Sleep and circadian rhythms are not only relevant candidates for the prediction of Li response. Many clinical guidelines and documents have been developed governing their exploration in routine clinical practice (Morgenthaler et al. 2007a, b; Schutte-Rodin et al. 2008; Adult Obstructive Sleep Apnea Task Force of the American Academy of Sleep Medicine et al. 2009). Sleep logs or diaries, sleep or morningness-eveningness questionnaires, and actigraphy (a watch-like tool containing an accelerometer) are potentially relevant and easy to implement in routine practice. Actigraphy also appears to be useful for evaluating the therapeutic response as an outcome measure (Morgenthaler et al. 2007a).

In conclusion, disrupted circadian rhythms are a core expression of susceptibility to $\mathrm{BD}$, persistent circadian abnormalities during euthymia are associated with relapses, and $\mathrm{Li}$ is known to act on circadian rhythms. Thus, circadian biomarkers are promising candidate biomarkers for the study of individual response to Li but cannot be used yet in clinical practice to predict this response. Future researches that specifically address this issue and prospective studies assessing the predictive value of circadian biomarkers are therefore highly expected. Possible circadian studies of the molecular signature of the response to $\mathrm{Li}$ may also help to better understand Li's action and to pave the way for more personalized medicine.

\footnotetext{
Competing interests

PA Geoffroy and S Sportiche declare that they have no competing interests. B. Etain and F. Bellivier have received honoraria and financial compensation as independent symposium speakers from Sanofi-Aventis, Lundbeck, AstraZeneca, Eli Lilly, Bristol-Myers Squibb, and Servier.
}

\section{Authors' contributions}

PAG, BE, SS, and FB contributed to and approved the submitted draft of the paper. All authors read and approved the final manuscript.

\section{Author details}

${ }^{1}$ Inserm, U1144, Paris F-75006, France. ${ }^{2}$ AP-HP, GH Saint-Louis - Lariboisière Fernand Widal, Pôle Neurosciences, Paris CEDEX 10 75475, France. ${ }^{3}$ Université 
Paris Diderot, UMR-S 1144, Paris F-75013, France. ${ }^{4}$ Fondation FondaMental, Créteil 94000, France. ${ }^{5}$ AP-HP, Hôpital H. Mondor - A. Chenevier, Pôle de Psychiatrie, Créteil 94000, France. ${ }^{6}$ INSERM, U955, Psychiatrie génétique, Créteil 94000, France.

\section{Received: 30 January 2014 Accepted: 26 March 2014} Published: 9 April 2014

\section{References}

Adult Obstructive Sleep Apnea Task Force of the American Academy of Sleep Medicine, Epstein LJ, Kristo D, Strollo PJ Jr, Friedman N, Malhotra A, Patil SP, Ramar K, Rogers R, Schwab RJ, Weaver EM, Weinstein MD (2009) Clinical guideline for the evaluation, management and long-term care of obstructive sleep apnea in adults. J Clin Sleep Med JCSM Off Publ Am Acad Sleep Med 5:263-276

Baldessarini RJ, Tondo L (2000) Does lithium treatment still work? Evidence of stable responses over three decades. Arch Gen Psychiatry 57:187-190

Can A, Schulze TG, Gould TD (2014) Molecular actions and clinical pharmacogenetics of lithium therapy. Pharmacol Biochem Behav. doi:10.1016/j.pbb.2014.02.004

Collins PY, Patel V, Joestl SS, March D, Insel TR, Daar AS, Scientific Advisory Board and the Executive Committee of the Grand Challenges on Global Mental Health, Anderson W, Dhansay MA, Phillips A, Shurin S, Walport M, Ewart W, Savill SJ, Bordin IA, Costello EJ, Durkin M, Fairburn C, Glass Rl, Hall W, Huang Y, Hyman SE, Jamison K, Kaaya S, Kapur S, Kleinman A, Ogunniyi A, Otero-Ojeda A, Poo M-M, Ravindranath V et al (2011) Grand challenges in global mental health. Nature 475:27-30, doi:10.1038/475027a

Etain B, Milhiet V, Bellivier F, Leboyer M (2011) Genetics of circadian rhythms and mood spectrum disorders. Eur Neuropsychopharmacol J Eur Coll Neuropsychopharmacol 21(Suppl 4):S676-682, doi:10.1016/j.euroneuro.2011.07.007

Etain B, Dumaine A, Bellivier F, Pagan C, Francelle L, Goubran-Botros H, Moreno S, Deshommes J, Moustafa K, Le Dudal K, Mathieu F, Henry C, Kahn J-P, Launay J-M, Mühleisen TW, Cichon S, Bourgeron T, Leboyer M, Jamain S (2012) Genetic and functional abnormalities of the melatonin biosynthesis pathway in patients with bipolar disorder. Hum Mol Genet. doi:10.1093/hmg/dds227

Garnham J, Munro A, Slaney C, Macdougall M, Passmore M, Duffy A, O'Donovan C, Teehan A, Alda M (2007) Prophylactic treatment response in bipolar disorder: results of a naturalistic observation study. J Affect Disord 104:185-190, doi:10.1016/j.jad.2007.03.003

Geddes JR, Miklowitz DJ (2013) Treatment of bipolar disorder. Lancet 381:1672-1682, doi:10.1016/50140-6736(13)60857-0

Geoffroy PA, Bellivier F, Scott J, Boudebesse C, Lajnef M, Gard S, Kahn J-P, Azorin J-M, Henry C, Leboyer M, Etain B (2013a) Bipolar disorder with seasonal pattern: clinical characteristics and gender influences. Chronobiol Int. doi:10.3109/07420528.2013.800091

Geoffroy PA, Boudebesse C, Henrion A, Jamain S, Henry C, Leboyer M, Bellivier F, Etain B (2013b) An ASMT variant associated with bipolar disorder influences sleep and circadian rhythms: a pilot study. Genes Brain Behav. doi:10.1111/ gbb.12103

Geoffroy PA, Etain B, Scott J, Henry C, Jamain S, Leboyer M, Bellivier F (2013c) Reconsideration of bipolar disorder as a developmental disorder: importance of the time of onset. J Physiol Paris. doi:10.1016/j.jphysparis.2013.03.006

Geoffroy PA, Bellivier F, Leboyer M, Etain B (2014) Can the response to mood stabilizers be predicted in bipolar disorder? Front Biosci Elite Ed 120-138, doi:10.2741/E696

Goodwin GM (2009) Evidence-based guidelines for treating bipolar disorder: revised second edition-recommendations from the British Association for Psychopharmacology. J Psychopharmacol Oxf Engl 23:346-388, doi:10.1177/ 0269881109102919

Grof P (2010) Sixty years of lithium responders. Neuropsychobiology 62:8-16, doi:10.1159/000314305

Grunze H, Vieta E, Goodwin GM, Bowden C, Licht RW, Moller H-J, Kasper S (2009) The World Federation of Societies of Biological Psychiatry (WFSBP) guidelines for the biological treatment of bipolar disorders: update 2009 on the treatment of acute mania. World J Biol Psychiatry Off J World Fed Soc Biol Psychiatry 10:85-116, doi:10.1080/15622970902823202

Grunze H, Vieta E, Goodwin GM, Bowden C, Licht RW, Möller H-J, Kasper S (2010) The World Federation of Societies of Biological Psychiatry (WFSBP) guidelines for the biological treatment of bipolar disorders: update 2010 on the treatment of acute bipolar depression. World J Biol Psychiatry Off J World Fed Soc Biol Psychiatry 11:81-109, doi:10.3109/15622970903555881
Hallam KT, Olver JS, Chambers V, Begg DP, McGrath C, Norman TR (2006) The heritability of melatonin secretion and sensitivity to bright nocturnal light in twins. Psychoneuroendocrinology 31:867-875, doi:10.1016/j. psyneuen.2006.04.004

Harvey AG (2008) Sleep and circadian rhythms in bipolar disorder: seeking synchrony, harmony, and regulation. Am J Psychiatry 165:820-829, doi:10.1176/appi.ajp.2008.08010098

Hasler G, Drevets WC, Gould TD, Gottesman II, Manji HK (2006) Toward constructing an endophenotype strategy for bipolar disorders. Biol Psychiatry 60:93-105, doi:10.1016/.j.biopsych.2005.11.006

Johnsson A, Engelmann W, Pflug B, Klemke W (1983) Period lengthening of human circadian rhythms by lithium carbonate, a prophylactic for depressive disorders. Int J Chronobiol 8:129-147

Jope RS, Roh M-S (2006) Glycogen synthase kinase-3 (GSK3) in psychiatric diseases and therapeutic interventions. Curr Drug Targets 7:1421-1434

Kato T, Kubota M, Kasahara T (2007) Animal models of bipolar disorder. Neurosci Biobehav Rev 31:832-842, doi:10.1016/j.neubiorev.2007.03.003

Kleindienst N, Engel R, Greil W (2005) Which clinical factors predict response to prophylactic lithium? A systematic review for bipolar disorders. Bipolar Disord 7:404-417, doi:10.1111/j.1399-5618.2005.00244.x

Klemfuss H (1992) Rhythms and the pharmacology of lithium. Pharmacol Ther 56:53-78

Klemfuss H, Kripke DF (1995) Antimanic drugs stabilize hamster circadian rhythms. Psychiatry Res 57:215-222

Maj M, Pirozzi R, Magliano L (1995) Nonresponse to reinstituted lithium prophylaxis in previously responsive bipolar patients: prevalence and predictors. Am J Psychiatry 152:1810-1811

McClung CA (2007) Circadian genes, rhythms and the biology of mood disorders. Pharmacol Ther 114:222-232, doi:10.1016/j.pharmthera.2007.02.003

McClung CA (2013) How might circadian rhythms control mood? Let me count the ways. Biol Psychiatry. doi:10.1016/j.biopsych.2013.02.019

Milhiet V, Etain B, Boudebesse C, Bellivier F (2011) Circadian biomarkers, circadian genes and bipolar disorders. J Physiol Paris. doi:10.1016/j.jphysparis.2011.07.002

Morgenthaler T, Alessi C, Friedman L, Owens J, Kapur V, Boehlecke B, Brown T, Chesson A Jr, Coleman J, Lee-Chiong T, Pancer J, Swick TJ (2007a) Practice parameters for the use of actigraphy in the assessment of sleep and sleep disorders: an update for 2007. Sleep 30:519-529

Morgenthaler TI, Lee-Chiong T, Alessi C, Friedman L, Aurora RN, Boehlecke B, Brown T, Chesson AL Jr, Kapur V, Maganti R, Owens J, Pancer J, Swick TJ, Zak R (2007b) Practice parameters for the clinical evaluation and treatment of circadian rhythm sleep disorders. An Am Acad Sleep Med Rep Sleep 30:1445-1459

Müller-Oerlinghausen B, Ahrens B, Grof E, Grof P, Lenz G, Schou M, Simhandl C, Thau K, Volk J, Wolf R (1992) The effect of long-term lithium treatment on the mortality of patients with manic-depressive and schizoaffective illness. Acta Psychiatr Scand 86:218-222

Pfennig A, Schlattmann P, Alda M, Grof P, Glenn T, Müller-Oerlinghausen B, Suwalska A, Rybakowski J, Willich SN, Bauer M, Berghöfer A (2010) Influence of atypical features on the quality of prophylactic effectiveness of long-term lithium treatment in bipolar disorders. Bipolar Disord 12:390-396, doi:10.1111/j.1399-5618.2010.00826.x

Pflug B, Engelmann W (1987) Chronobiology of lithium-studies on healthy, middle-aged women. Pharmacopsychiatry 20:181-188, doi:10.1055/s-20071017099

Phillips ML, Kupfer DJ (2013) Bipolar disorder diagnosis: challenges and future directions. Lancet 381:1663-1671, doi:10.1016/S0140-6736(13)60989-7

Prickaerts J, Moechars D, Cryns K, Lenaerts I, van Craenendonck H, Goris I, Daneels G, Bouwknecht JA, Steckler T (2006) Transgenic mice overexpressing glycogen synthase kinase 3beta: a putative model of hyperactivity and mania. J Neurosci Off J Soc Neurosci 26:9022-9029, doi:10.1523/ JNEUROSCI.5216-05.2006

Roybal K, Theobold D, Graham A, DiNieri JA, Russo SJ, Krishnan V, Chakravarty S, Peevey J, Oehrlein N, Birnbaum S, Vitaterna MH, Orsulak P, Takahashi JS, Nestler EJ, Carlezon WA Jr, McClung CA (2007) Mania-like behavior induced by disruption of CLOCK. Proc Natl Acad Sci U S A 104:6406-6411, doi:10.1073/pnas.0609625104

Rybakowski JK, Dembinska D, Kliwicki S, Akiskal KK, Akiskal HH (2013) TEMPS-A and long-term lithium response: positive correlation with hyperthymic temperament. J Affect Disord 145:187-189, doi:10.1016/j.jad.2012.07.028 Schulze TG, Alda M, Adli M, Akula N, Ardau R, Bui ET, Chillotti C, Cichon S, Czerski P, Del Zompo M, Detera-Wadleigh SD, Grof P, Gruber O, Hashimoto R, Hauser 
J, Hoban R, Iwata N, Kassem L, Kato T, Kittel-Schneider S, Kliwicki S, Kelsoe JR, Kusumi I, Laje G, Leckband SG, Manchia M, Macqueen G, Masui T, Ozaki N, Perlis RH et al (2010) The International Consortium on Lithium Genetics (ConLiGen): an initiative by the NIMH and IGSLI to study the genetic basis of response to lithium treatment. Neuropsychobiology 62:72-78, doi:10.1159/ 000314708

Schutte-Rodin S, Broch L, Buysse D, Dorsey C, Sateia M (2008) Clinical guideline for the evaluation and management of chronic insomnia in adults. J Clin Sleep Med JCSM Off Publ Am Acad Sleep Med 4:487-504

Solomon DA, Keitner GI, Miller IW, Shea MT, Keller MB (1995) Course of illness and maintenance treatments for patients with bipolar disorder. J Clin Psychiatry 56:5-13

Yatham LN, Kennedy SH, Schaffer A, Parikh V, Beaulieu S, O'Donovan C, MacQueen G, Mclntyre RS, Sharma V, Ravindran A, Young LT, Young AH, Alda M, Milev R, Vieta E, Calabrese JR, Berk M, Ha K, Kapczinski F (2009) Canadian Network for Mood and Anxiety Treatments (CANMAT) and International Society for Bipolar Disorders (ISBD) collaborative update of CANMAT guidelines for the management of patients with bipolar disorder: update 2009. Bipolar Disord 11:225-255, doi:10.1111/j.1399-5618.2009.00672.x

Yerevanian BI, Choi YM (2013) Impact of psychotropic drugs on suicide and suicidal behaviors. Bipolar Disord 15:594-621, doi:10.1111/bdi.12098

doi:10.1186/2194-7511-2-5

Cite this article as: Geoffroy et al:: Circadian biomarkers in patients with bipolar disorder: promising putative predictors of lithium response. International Journal of Bipolar Disorders 2014 2:5.

\section{Submit your manuscript to a SpringerOpen ${ }^{\circ}$} journal and benefit from:

- Convenient online submission

- Rigorous peer review

- Immediate publication on acceptance

- Open access: articles freely available online

- High visibility within the field

- Retaining the copyright to your article 